\title{
Building a Company Step by Step, Ch. 8: Introduction to Customer Validation
}

\author{
Jon Eckhardt (University of Wisconsin-Madison)
}

KEYWORDS: Entrepreneurship, Startups, customer discovery.

EIX is featuring interviews that explore the principles outlined in Steve Blank and Bob Dorf's book, "The Startup Owners Manual: The Step-by-Step Guide for Building a Great Company." (https://www.amazon.com/Startup-Owners-ManualStep-Step/dp/1119690684) This interview with Dan Reich explores Chapter 8: Introduction to Customer Validation.

Reich has started several companies, which in total have raised over $\$ 100$ million in venture capital. He is the co-founder of Troops, a technology company building a mobile customer relationship management system, and Tula, a health and beauty line sold through QVC and at Ulta Beauty stores.

In this interview with EIX Editor Jon Eckhardt, Reich talks about the importance of testing and experimenting to determine how a product or service will be sold, before committing money, people and infrastructure towards something that may not work out.

\section{Listen}

Listen to this interview on our Soundcloud podcast channel.

Link to video

EIX

(https://soundcloud.com/user-876519212-189256831).

Ch 8 Dan Reich

(https://soundcloud.com/user-876519212-189256831/c

h-8-dan-reich) 